Cite this: J. Mater. Chem. A, 2014, 2, 4361

Received 19th December 2013 Accepted 2nd January 2014

DOI: 10.1039/c3ta15294d

www.rsc.org/MaterialsA

\section{A metal-oxide catalyst enhanced the desorption properties in complex metal hydrides}

\author{
Tengfei Zhang, ${ }^{\text {*a }}$ Shigehito Isobe, ${ }^{\text {*ab }}$ Yongming Wang, ${ }^{a}$ Hiroshi Oka, ${ }^{a}$ \\ Naoyuki Hashimoto ${ }^{a}$ and Somei Ohnuki ${ }^{a}$
}

In this study, $\mathrm{LiTi}_{2} \mathrm{O}_{4}$ was synthesized as a possible catalyst for complex metal hydrides. $\mathrm{LiTi}_{2} \mathrm{O}_{4}$ was stable in the sample after high-energy ball milling and heat treatment. $\mathrm{LiTi}_{2} \mathrm{O}_{4}$ exhibited a catalytic effect among the samples of $\mathrm{MgH}_{2}, \mathrm{LiAlH}_{4}$ and $\mathrm{LiNH}_{2}$. The desorption kinetics and the purity of the desorbed hydrogen gas have been improved by doping $\mathrm{LiTi}_{2} \mathrm{O}_{4}$. Furthermore, the catalytic mechanism of $\mathrm{LiTi}_{2} \mathrm{O}_{4}$ was discussed in accordance with the experimental results.

\section{Introduction}

Hydrogen is a kind of sustainable energy carrier compared to conventional ones such as fossil fuels. It has advantages such as being clean, is environmentally friendly and forms water as a non-polluting product during practical applications. ${ }^{1}$ Accordingly, the reduction of our dependence on fossil fuels and emissions of pollutants and greenhouse gases could be realized by using hydrogen as a primary fuel successfully. This would have a great influence on both changing energy structure and improving global warming. Recently hydrogen energy has been actively investigated in terms of production, storage and application (comprising combustion engines in vehicles and power application). ${ }^{2}$ Nowadays, compressed gaseous hydrogen is used in prototype and liquid form in advanced tank systems. ${ }^{3}$ However, storing hydrogen in solid-state materials has definite advantages on accessible hydrogen content and energy efficiency compared to complex system that use high-pressure gas or cryogenic liquid. A series of storage materials have been proposed, such as metal-hydrides, alanates and amides. While the hydrogen capacity of complex metal hydrides is reasonable (often in the 3-12 wt\% range), relatively high thermal stability, slow kinetics of the pure hydrides, undesirable by-product gases (e.g. ammonia) and irreversibility on cycling are still limitations for on-board applications. ${ }^{4}$

Extensive efforts are currently being made for the improvement of hydrogen storage properties by improving the absorption/desorption kinetics, reducing the operating temperatures and improving the purity of the desorbed hydrogen gas. ${ }^{5}$ One of the strategies for the improvement of hydrogen storage properties is the addition of catalysts. Ti compounds have been well

${ }^{a}$ Graduate School of Engineering, Hokkaido University, N-13, W-8, Sapporo 060-8628, Japan.E-mail: isobe@eng.hokudai.ac.jp; zhangtengfei@eng.hokudai.ac.jp

${ }^{b}$ Creative Research Institution, Hokkaido University, N-21, W-10, Sapporo, 001-0021, Japan known to catalyze the dehydrogenation of complex aluminium hydrides in solution. Wieberg et al. in 1951 observed that Ti catalysed the dehydrogenation of $\mathrm{LiAlH}_{4}$ in a diethyl ether suspension. ${ }^{6}$ A breakthrough came when Bogdanovic and Schwickardi certificated that doping a few mol\% $\mathrm{Ti}$ in the complex metal hydride $\mathrm{NaAlH}_{4}$ lowered the dehydrogenation temperature, improved the kinetics and allowed rehydrogenation of the decomposition products. ${ }^{7}$ This is an indication that Ti worked effectively for solid-state $\mathrm{NaAlH}_{4}$. Interest in using complex metal hydrides as hydrogen storage materials has dramatically reawakened. Meanwhile, the catalytic effect of $\mathrm{Ti}$ compounds was also found in a $\mathrm{LiH} / \mathrm{LiNH}_{2}$ system which was reversible and had a high hydrogen capacity of $6.5 \mathrm{wt} \%{ }^{8}$ The absorption/desorption kinetics and the purity of the desorbed hydrogen gas had been improved. Among the metal hydrides, $\mathrm{MgH}_{2}$ exhibits a high hydrogen capacity up to $7.6 \mathrm{wt} \%$. However, the absorption and desorption reactions of $\mathrm{Mg} / \mathrm{MgH}_{2}$ itself are too slow. Some of the researchers reported that $\mathrm{Ti}$ compounds had a catalytic effect on the absorption and desorption. ${ }^{9-11}$ Subsequently, Hanada et al. reported the valence state of the Ti compounds that were doped in $\mathrm{MgH}_{2} \cdot{ }^{12}$ However, the catalyst state of $\mathrm{Ti}$ is not the same as the original after ballmilling and/or heat treatment. ${ }^{\mathbf{1 2 , 1 3}}$ In this case, the mechanism of the catalytic effect is difficult to understand clearly due to the instability of Ti compounds.

Normally, the reactions that occur between the solid phases for complex metal hydrides are solid-state reactions. Diffusion plays an important role in the solid-state reactions since they require the coming together of reactive species. The rigid structure makes solids different from liquids and gases. The kinetics of solid-state reactions is therefore greatly dependent on the crystal structure and its defects. Based on these results, one proposal for improving the kinetics of the solid-state reaction is increasing the mobility of ions, such as $\mathrm{Li}^{+}, \mathrm{Na}^{+}$and $\mathrm{H}^{-}$ in the complex metal hydrides. This process would progress by doping the catalyst, especially with Ti compounds. Our previous 
study suggested that $\mathrm{LiTi}_{2} \mathrm{O}_{4}$ was discovered by transmission electron microscopy (TEM) in the $\mathrm{Li}-\mathrm{N}-\mathrm{H}$ sample which was doped with $\mathrm{TiCl}_{3}$ as the catalyst. ${ }^{13}$ The catalytic Ti compounds were active at the interface between $\mathrm{LiH}$ and $\mathrm{LiNH}_{2}$. Herein, we choose $\mathrm{LiTi}_{2} \mathrm{O}_{4}$ as the catalyst for hydrogen storage materials in lithium alanate, magnesium hydride and lithium amides. As a result of their investigation, hydrogen can be desorbed via the following reaction:

$$
\begin{gathered}
\mathrm{LiAlH}_{4} \leftrightarrow \mathrm{LiH}+\mathrm{Al}+3 / 2 \mathrm{H}_{2} \\
\mathrm{MgH}_{2} \leftrightarrow \mathrm{Mg}+\mathrm{H}_{2} \\
\mathrm{LiH}+\mathrm{LiNH}_{2} \leftrightarrow \mathrm{Li}_{2} \mathrm{NH}+\mathrm{H}_{2}
\end{gathered}
$$

For the case of $\mathrm{LiAlH}_{4}$, eqn (1) can be recast as a two step reaction as follows:

$$
\begin{aligned}
& \mathrm{LiAlH}_{4} \rightarrow 1 / 3 \mathrm{Li}_{3} \mathrm{AlH}_{6}+2 / 3 \mathrm{Al}+\mathrm{H}_{2} \\
& 1 / 3 \mathrm{Li}_{3} \mathrm{AlH}_{6} \rightarrow \mathrm{LiH}+1 / 3 \mathrm{Al}+1 / 2 \mathrm{H}_{2}
\end{aligned}
$$

Consequently, the catalytic effect of $\mathrm{LiTi}_{2} \mathrm{O}_{4}$ will be discovered for samples with the aim of enhancing hydrogen desorption properties in this study.

\section{Experimental}

\subsection{Sample preparation}

Powders of $\mathrm{LiAlH}_{4}$ (95\%), $\mathrm{Li}_{2} \mathrm{CO}_{3}$ (99.997\%), $\mathrm{TiO}_{2}$ (99\%), $\mathrm{Ti}_{2} \mathrm{O}_{3}$ (99.9\%), $\mathrm{LiH}(95 \%)$ and $\mathrm{LiNH}_{2}$ (95\%) were purchased from Sigma-Aldrich. $\mathrm{MgH}_{2}$ (98\%) powder was purchased from Alfa Aesar. The single phase of $\mathrm{LiTi}_{2} \mathrm{O}_{4}$ was synthesized by a two-step solid-state reaction. $\mathrm{Li}_{2} \mathrm{Ti}_{2} \mathrm{O}_{5}$ forms as an intermediate compound. ${ }^{14}$ The reaction equations used here are:

$$
\begin{gathered}
\mathrm{Li}_{2} \mathrm{CO}_{3}+2 \mathrm{TiO}_{2} \rightarrow \mathrm{Li}_{2} \mathrm{Ti}_{2} \mathrm{O}_{5}+\mathrm{CO}_{2} \\
\mathrm{Li}_{2} \mathrm{Ti}_{2} \mathrm{O}_{5}+\mathrm{Ti}_{2} \mathrm{O}_{3} \rightarrow 2 \mathrm{LiTi}_{2} \mathrm{O}_{4}
\end{gathered}
$$

The synthesis method of $\mathrm{LiTi}_{2} \mathrm{O}_{4}$ according to Xu et al. has been used. ${ }^{15}$ Considering the volatility of $\mathrm{Li}$, it was hard to get the exact composition of $\mathrm{Li}$. Here an excess molar fraction 0.15 of $\mathrm{Li}_{2} \mathrm{CO}_{3}$ is added in eqn (6) for $\mathrm{LiTi}_{2} \mathrm{O}_{4}$. An additional factor is the sensitivity of $\mathrm{LiTi}_{2} \mathrm{O}_{4}$ to air. This issue was mentioned by several groups, ${ }^{\mathbf{1 6}-\mathbf{1 8}}$ regardless of the preparation method used. The aging reaction is the topotactic oxidation of $\mathrm{LiTi}_{2} \mathrm{O}_{4}$. $\mathrm{LiTi}_{2} \mathrm{O}_{4}$ reacts with oxygen or $\mathrm{H}_{2} \mathrm{O}$ in air and is progressively transformed into $\mathrm{Li}_{1-x} \mathrm{Ti}_{2} \mathrm{O}_{4}(0 \leq x \leq 0.8)$. The polycrystalline sample is stored in Ar atmosphere in order to avoid the aging reaction with oxygen and moisture.

Typically, in order to ensure a homogeneous mixing between the starting materials and the additive, a ball-milling equipment (Fritsch P7) is used. Samples of $\mathrm{LiAlH}_{4}$ and $0.5 \mathrm{~mol} \%$ $\mathrm{LiTi}_{2} \mathrm{O}_{4}$ were milled for $2 \mathrm{~h}$. The samples, mixtures of $\mathrm{MgH}_{2}$ and $1 \mathrm{~mol} \% \mathrm{LiTi}_{2} \mathrm{O}_{4}$, were milled for $20 \mathrm{~h}$. $\mathrm{LiNH}_{2}$ and $\mathrm{LiH}$ powders with 1 : 1.2 molar ratio and $0.5 \mathrm{~mol} \% \mathrm{LiTi}_{2} \mathrm{O}_{4}$ were milled for $2 \mathrm{~h}$. The total weight for each ball-milled sample was $300 \mathrm{mg}$. In the high energy ball-milling process, powder and 20 steel balls (SUJ-2) with a diameter of $7 \mathrm{~mm}$ were brought into a Cr steel pot (SKD-11) and milled at $400 \mathrm{rpm}$ under a hydrogen gas (99.9999\% purity) at a pressure of $1 \mathrm{MPa}$ at room temperature. The ball-to-powder ratio was $100: 1$. The milling was interrupted every $1 \mathrm{~h}$ for $30 \mathrm{~min}$ in order to prevent frictional heat during the milling process.

\subsection{Characterization measurements}

Structure properties were characterized by X-ray diffraction (XRD) measurement. A sample was firstly put on a glass plate in a glove box. Then the glass plate was covered with a plastic film to protect the sample from contact with air. The plastic film does not have any obvious influence on the obtained XRD patterns. The samples were measured with a diffraction $2 \theta$ angle from $10^{\circ}$ to $90^{\circ}$ under a speed of $0.04^{\circ}$ per step. Furthermore, after the milling process, the mixtures were examined by thermogravimetry and differential thermal analysis (TG-DTA) equipment (HITACHI BRUKER TAPS3000S) combined with thermal gas desorption mass spectrometry (TDMS). TG-DTA equipment was installed in another glove box to avoid exposing the samples to air in their measurements.

\section{Results and discussion}

$\mathrm{LiTi}_{2} \mathrm{O}_{4}$ was synthesized by sintering a mixture of $\mathrm{Li}_{2} \mathrm{Ti}_{2} \mathrm{O}_{5}$ and $\mathrm{Ti}_{2} \mathrm{O}_{3}$ at $880^{\circ} \mathrm{C}$ under a pressure less than $10^{-4}$ Pa. Fig. 1 shows the powder X-ray diffraction (XRD) profile. There were no apparent impurities in the product of the single phase $\mathrm{LiTi}_{2} \mathrm{O}_{4}$. The color of this single phase was black, which is consistent with previous reports. ${ }^{19}$ The stability of $\mathrm{LiTi}_{2} \mathrm{O}_{4}$ is reflected by the XRD patterns in Fig. 2. Three samples after high-energy ball milling and dehydrogenation, $0.5 \mathrm{~mol}_{\%} \mathrm{LiTi}_{2} \mathrm{O}_{4}+99.5 \mathrm{~mol} \%$ $\mathrm{LiAlH}_{4}$ mixture, $1 \mathrm{~mol} \% \mathrm{LiTi}_{2} \mathrm{O}_{4}+99 \mathrm{~mol} \% \mathrm{MgH}_{2}$ mixture and the composite of $\mathrm{LiH}$ and $\mathrm{LiNH}_{2}$ with $0.5 \mathrm{~mol}^{2} \mathrm{LiTi}_{2} \mathrm{O}_{4}$, were prepared for XRD measurement. The results indicated that the

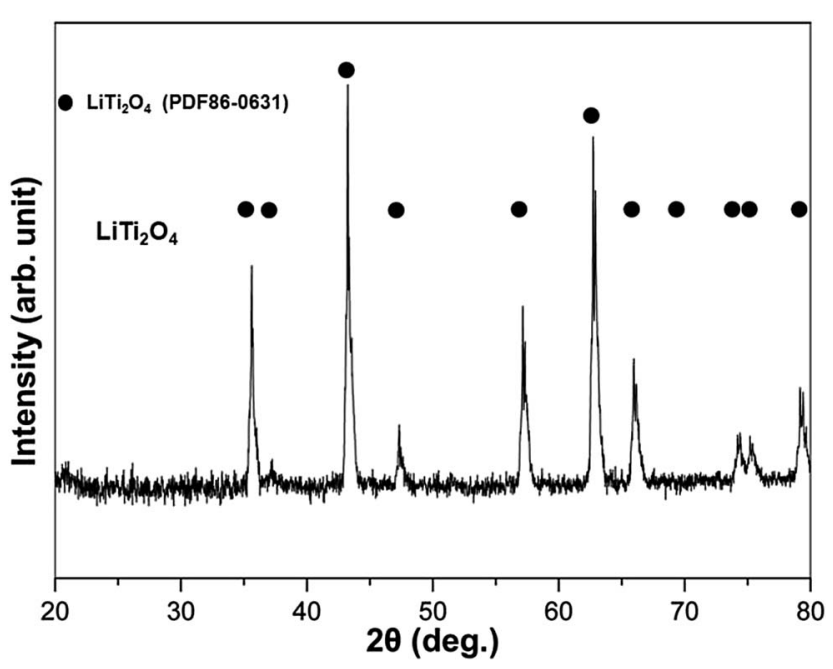

Fig. 1 XRD pattern of the single phase $\mathrm{LiTi}_{2} \mathrm{O}_{4}$. 

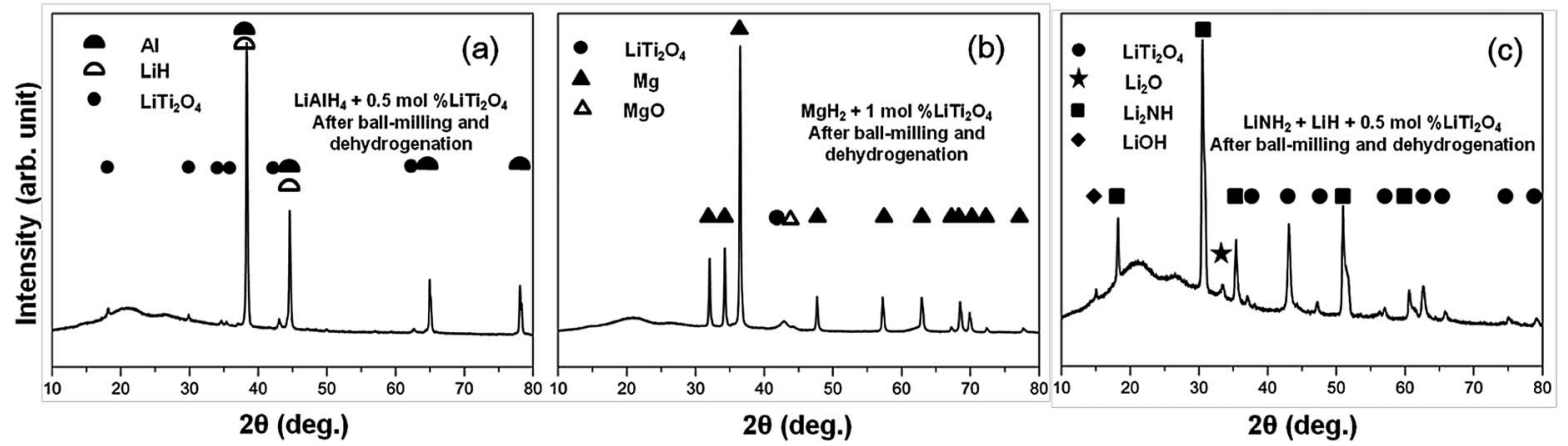

Fig. 2 XRD patterns of the samples after high-energy ball milling and dehydrogenation: (a) 0.5 mol\% $\mathrm{LiTi}_{2} \mathrm{O}_{4}+99.5 \mathrm{~mol}^{2} \mathrm{LiAlH}_{4} \mathrm{mixture}_{\text {, }}(\mathrm{b}) 1$ mol\% $\mathrm{LiTi}_{2} \mathrm{O}_{4}+99$ mol\% $\mathrm{MgH}_{2}$ mixture, (c) the composite of $\mathrm{LiH}$ and $\mathrm{LiNH}_{2}$ with $0.5 \mathrm{~mol} \% \mathrm{LiTi}_{2} \mathrm{O}_{4}$.

structure of $\mathrm{LiTi}_{2} \mathrm{O}_{4}$ was the same as the single phase of the raw $\mathrm{LiTi}_{2} \mathrm{O}_{4}$ after high-energy ball milling and dehydrogenation.

Fig. 3 shows the TG-DTA results of the as received $\mathrm{LiAlH}_{4}$ and the $0.5 \mathrm{~mol} \% \mathrm{LiTi}_{2} \mathrm{O}_{4}+99.5 \mathrm{~mol} \% \mathrm{LiAlH}_{4}$ mixture. It could be confirmed that during the examined temperature range, the dehydrogenation process showed rather different behavior from these two samples. In the case of the as received sample, two conspicuous peaks appeared around $165-180{ }^{\circ} \mathrm{C}$. The endothermic peak $\left(170^{\circ} \mathrm{C}\right)$ resulted from the melting of $\mathrm{LiAlH}_{4}$. After the endothermic peak, there was an exothermic peak $\left(179.5{ }^{\circ} \mathrm{C}\right)$ that indicated the decomposition of liquid $\mathrm{LiAlH}_{4}$. The reaction started at $160{ }^{\circ} \mathrm{C}$ and ended at $240{ }^{\circ} \mathrm{C}$. The total weight loss was $6.4 \mathrm{wt} \%$. In the case of the mixed sample, the hydrogen desorption started at $100{ }^{\circ} \mathrm{C}$, and the whole decomposition of $\mathrm{LiAlH}_{4}$ was complete at around $220^{\circ} \mathrm{C}$. Two endothermic peaks could be seen from the DTA curve. The peak temperature of each peak was $160{ }^{\circ} \mathrm{C}$ and $210{ }^{\circ} \mathrm{C}$. Accordingly, some authors have calculated in their reports that the enthalpy of the first dehydrogenation of $\mathrm{LiAlH}_{4}$ with an additive is in

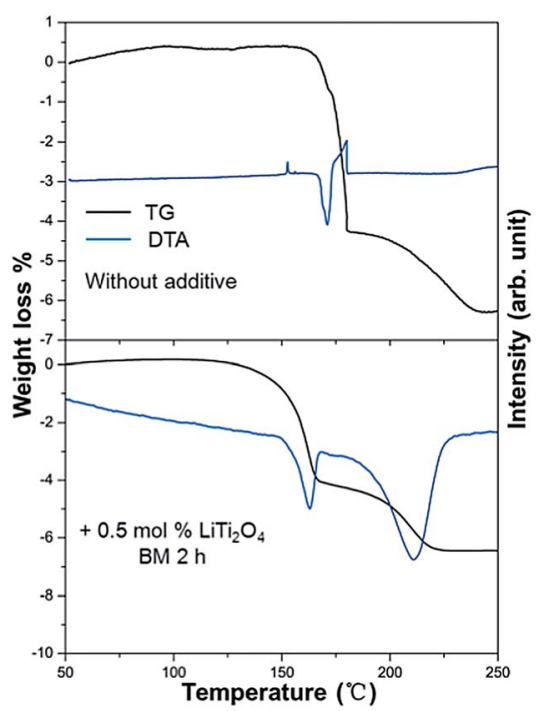

Fig. 3 Differential thermal analysis and corresponding weight loss for the dehydrogenation of the as received $\mathrm{LiAlH}_{4}$ and the $0.5 \mathrm{~mol} \%$ $\mathrm{LiTi}_{2} \mathrm{O}_{4}+99.5$ mol\% $\mathrm{LiAlH}_{4}$ mixture. agreement with the enthalpy difference between the melting transition and the exothermic decomposition immediately following it for as received $\mathrm{LiAlH}_{4} \cdot{ }^{20-23}$ Consequently, the composite's endothermic-exothermic peak at $170-180^{\circ} \mathrm{C}$ in the sample without the additive is in agreement with the absorption of latent heat of melting by $\mathrm{LiAlH}_{4}$ with fast decomposition of $\mathrm{Li}_{3} \mathrm{AlH}_{6}$ and desorption of $\mathrm{H}_{2}$, and immediate releasing the latent heat of fusion of $\mathrm{Li}_{3} \mathrm{AlH}_{6}$ with desorption of $\mathrm{H}_{2}$. Hence, the first dehydrogenation of $\mathrm{LiAlH}_{4}$ is intrinsically endothermic. Doping $\mathrm{LiAlH}_{4}$ with $\mathrm{LiTi}_{2} \mathrm{O}_{4}$ improved its thermal decomposition, bringing this dehydrogenation below the melting point of $\mathrm{LiAlH}_{4}$ and separating it from the complex melting-desorptionsolidification event that appears at $170{ }^{\circ} \mathrm{C}$ for the undoped sample. This result indicated that $\operatorname{LiTi}_{2} \mathrm{O}_{4}$ has some catalytic effect on the lithium alanate.

The TG-DTA results of the milled $\mathrm{MgH}_{2}$ and the $1 \mathrm{~mol} \%$ $\mathrm{LiTi}_{2} \mathrm{O}_{4}+99 \mathrm{~mol} \% \mathrm{MgH}_{2}$ mixture are shown in Fig. 4. There were two endothermic peaks for the milled $\mathrm{MgH}_{2}$ sample during the measurement. Dehydrogenation started around

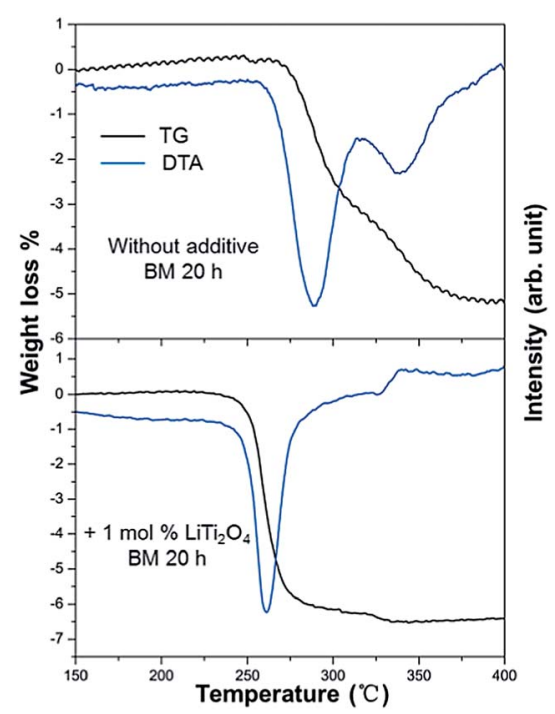

Fig. 4 Differential thermal analysis and corresponding weight loss for the dehydrogenation of the milled $\mathrm{MgH}_{2}$ and the 1 mol\% $\mathrm{LiTi}_{2} \mathrm{O}_{4}+99$ mol\% $\mathrm{MgH}_{2}$ mixture. 
$260{ }^{\circ} \mathrm{C}$ and ended at $380{ }^{\circ} \mathrm{C}$. The peak temperature for each peak was $290{ }^{\circ} \mathrm{C}$ and $340{ }^{\circ} \mathrm{C}$. The weight loss of $5.1 \mathrm{wt} \%$ was much less than the theoretical value of $7.6 \mathrm{wt} \%$, which indicated an incomplete decomposition of the milled sample under the conditions of heating up to $400{ }^{\circ} \mathrm{C}$ at a rate of $5{ }^{\circ} \mathrm{C} \mathrm{min}^{-1}$. For the sample with an additive the DTA curve showed that hydrogen desorption started at $220{ }^{\circ} \mathrm{C}$ and finished at $330{ }^{\circ} \mathrm{C}$. There was only one main endothermic peak for the mixture sample during the measurements. The peak temperature was at $260{ }^{\circ} \mathrm{C}$. A weight loss of $6.6 \mathrm{wt} \%$ was achieved from the TG measurement compared with the theoretical value of $7.0 \mathrm{wt} \%$. The difference between the experimental value and the theoretical value was caused by impurities in the original sample, such as MgO. The much better hydrogen desorption kinetics of the mixture sample was attributed to the catalytic effect of $\mathrm{LiTi}_{2} \mathrm{O}_{4}$. Recently, $\mathrm{Nb}_{2} \mathrm{O}_{5}$ doped $\mathrm{MgH}_{2}$ has been actively studied. The sluggish sorption kinetics of $\mathrm{MgH}_{2}$ can be improved dramatically to release $6 \mathrm{wt} \%$ of reversible hydrogen at $250{ }^{\circ} \mathrm{C} .^{\mathbf{8} 24,25}$ Hanada et al. reported that $\mathrm{MgH}_{2}$ with $1 \mathrm{~mol} \%$ $\mathrm{Nb}_{2} \mathrm{O}_{5}$ milled for $20 \mathrm{~h}$, was able to release $4.5 \mathrm{wt} \% \mathrm{H}_{2} \cdot{ }^{26,27}$ After $\mathrm{LiTi}_{2} \mathrm{O}_{4}$ was introduced to this system, the kinetics of $\mathrm{MgH}_{2}$ has been accelerated at the same level compared with previous work. ${ }^{27}$

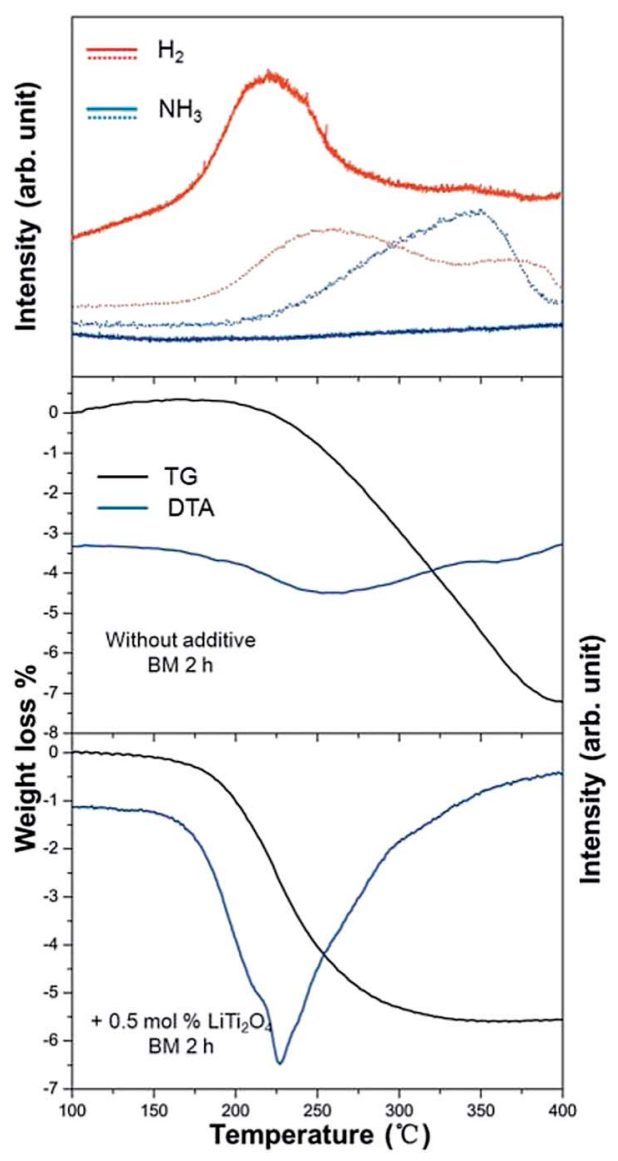

Fig. 5 Mass spectra of gas desorption for the dehydrogenation of $\mathrm{LiNH}_{2}+\mathrm{LiH}$ mixture without any additive (dot line) and with $0.5 \mathrm{~mol} \%$ $\mathrm{LiTi}_{2} \mathrm{O}_{4}$ (solid line); corresponding weight loss and differential thermal analysis for each sample.
The dehydrogenation process of a composite of $\mathrm{LiH}$ and $\mathrm{LiNH}_{2}$ with $0.5 \mathrm{~mol} \% \mathrm{LiTi}_{2} \mathrm{O}_{4}$ additive was investigated. Fig. 5 presents the TDMS results. The sample of $\mathrm{LiH}$ and $\mathrm{LiNH}_{2}$ with $\mathrm{LiTi}_{2} \mathrm{O}_{4}$ showed a sharp $\mathrm{H}_{2}$ peak. The peak temperature was at $227^{\circ} \mathrm{C}$. No ammonia was detected during dehydrogenation. To the best of our knowledge, addition of $\mathrm{LiTi}_{2} \mathrm{O}_{4}$ to the system as a catalyst resulted in the lowest desorption temperature observed so far, compared with well known catalysts $\left(\mathrm{BN}, \mathrm{Si}, \mathrm{TiCl}_{3}\right){ }^{28}$ However, hydrogen and ammonia were released from the sample without $\mathrm{LiTi}_{2} \mathrm{O}_{4}$. The broad hydrogen desorption curves and obvious ammonia emission can be seen in the temperature range from $200{ }^{\circ} \mathrm{C}$ to $400{ }^{\circ} \mathrm{C}$. The results demonstrated clearly that the purity of the desorbed hydrogen gas was improved after doping with $\mathrm{LiTi}_{2} \mathrm{O}_{4}$. During heating, the decomposition of the $\mathrm{LiNH}_{2}+\mathrm{LiH}$ mixture was observed to start at $200{ }^{\circ} \mathrm{C}$ and complete at $400{ }^{\circ} \mathrm{C}$. By contrast, the addition of $\mathrm{LiTi}_{2} \mathrm{O}_{4}$ led to full desorption within the temperature range of $150-310^{\circ} \mathrm{C}$. The total weight loss for $\mathrm{LiNH}_{2}+\mathrm{LiH}+0.5 \mathrm{~mol} \% \mathrm{LiTi}_{2} \mathrm{O}_{4}$ was $5.7 \mathrm{wt}$ $\%$ instead of the $7.5 \mathrm{wt} \%$ for $\mathrm{LiNH}_{2}+\mathrm{LiH}$. Accordingly, a lower dehydrogenation temperature indicated that desorption properties can be improved greatly by adding $\mathrm{LiTi}_{2} \mathrm{O}_{4}$ as the catalyst.

On the basis of these experimental results, it can be figured out that $\mathrm{LiTi}_{2} \mathrm{O}_{4}$ worked catalytically for the reactions of lithium alanate, magnesium hydride and lithium amides on hydrogen desorption. As far as the catalytic mechanism of a Ti compound is concerned, some investigations have been performed. For the situations of lithium alanate and magnesium hydride, the explanation of how Ti compounds might work as a catalyst is that it destabilizes the metal-H bonds of the complex metal hydrides, such as the bonding between $\mathrm{Mg}-\mathrm{H}$ or $\mathrm{Al}-\mathrm{H}$. Sandrock et al. suggested that the Ti compound aided the "breaking and re-forming of covalent metal-H bonds". ${ }^{29}$ Subsequently, starting from 2005, a number of researchers have investigated similar ideas. ${ }^{30-35}$ Additionally, Seong $\mathrm{Mu}$ Jo certificated that $\mathrm{LiTi}_{2} \mathrm{O}_{4}$ nanofibers could absorb/desorb hydrogen at ambient temperature. ${ }^{36}$ That means $\mathrm{LiTi}_{2} \mathrm{O}_{4}$ could probably have a similar effect on helping to weaken the metal-H bond, and suggests the increasing lability of the hydride. The catalytic effect is generated by nanocontacts between the sample and $\mathrm{LiTi}_{2} \mathrm{O}_{4}$ in the mechanical milling process.

For the case of a lithium-nitrogen-hydrogen system, David et al. proposed in their report that the reaction mechanism was based on $\mathrm{Li}^{+}$migration across reactive interfaces between $\mathrm{LiH}$ and $\mathrm{LiNH}_{2} \cdot{ }^{37}$ Additionally, our previous results revealed that the catalytic effect is generated by nanocontacts between the sample and the Ti compound in the interface..$^{13}$ In the present studies, $\mathrm{LiTi}_{2} \mathrm{O}_{4}$ has been experimentally proven to have a catalytic effect on the $\mathrm{Li}-\mathrm{N}-\mathrm{H}$ system. The catalytic mechanism might be related to the crystal structure of $\mathrm{LiTi}_{2} \mathrm{O}_{4} \cdot \mathrm{LiTi}_{2} \mathrm{O}_{4}$ has a spinel-structure, where $\mathrm{Li}^{+}$ions could go through into/out of $\mathrm{LiTi}_{2} \mathrm{O}_{4}$ without high energy barriers at ambient temperature. ${ }^{38}$ Because of these characteristics of the crystal structure, $\mathrm{LiTi}_{2} \mathrm{O}_{4}$ has a high diffusion rate of $\mathrm{Li}^{+}$which is reported to be $10^{-8} \mathrm{~cm}^{2}$ $\mathrm{s}^{-1} \cdot{ }^{39}$ All of these could help increase $\mathrm{Li}^{+}$ion mobility in the $\mathrm{Li}-$ $\mathrm{N}-\mathrm{H}$ system. Accordingly, the catalytic effect of $\mathrm{LiTi}_{2} \mathrm{O}_{4}$ probably results from the increase of the $\mathrm{Li}^{+}$ion mobility to improve the reaction kinetics. Meanwhile, the improvement of desorption 
kinetics could lead to the consumption of $\mathrm{LiNH}_{2}$ and therefore the ammonia emission at high temperature could be restricted.

\section{Conclusions}

In conclusion, we performed a study on the catalytic effect of $\mathrm{LiTi}_{2} \mathrm{O}_{4}$ in complex metal hydrides, such as magnesium hydride, lithium alanate and lithium amide. The purity and stability of $\mathrm{LiTi}_{2} \mathrm{O}_{4}$ were confirmed by XRD results. $\mathrm{LiTi}_{2} \mathrm{O}_{4}$ was stable after high energy ball milling and heat treatment. After adding $\mathrm{LiTi}_{2} \mathrm{O}_{4}$, the dehydrogenation temperature was decreased effectively among the three kinds of materials. The desorption kinetics and the purity of the desorbed hydrogen gas have been improved by doping with $\mathrm{LiTi}_{2} \mathrm{O}_{4}$. The catalytic mechanism for complex metal hydrides was also discussed in this study. This is the first time these results have appeared in the literature. It is hoped that they are helpful for hydrogen storage materials as well as fuel cell industries.

\section{Acknowledgements}

This work was partially supported by L-station (Hokkaido University) and the "Nanotechnology Platform" program of MEXT, Japan. I would like to thank my colleagues, Dr Tao Ma and Mr Yudai Ikarashi, for their cooperation on my work.

\section{References}

1 A. Züttel and L. Schlapbach, Nature, 2001, 414, 353.

2 http://www.hydrogen.energy.gov/.

3 R. von Helmolt and U. Eberle, J. Power Sources, 2007, 165, 833.

4 T. Frankcombe, Chem. Rev., 2012, 112, 2164.

5 H. Wu, ChemPhysChem, 2008, 9, 2157.

6 E. Wieberg, R. Bauer, M. Schmidt and R. Z. Uson, Z. Naturforsch., B: Anorg. Chem., Org. Chem., 1951, 6, 393.

7 B. Bogdanović and M. Schwickardi, J. Alloys Compd., 1997, 253, 1. 8 T. Ichikawa, N. Hanada, S. Isobe, H. Y. Leng and H. Fujii, J. Alloys Compd., 2005, 404-406, 435.

9 G. Barkhordarian, T. Klassen and R. Bormann, Scr. Mater., 2003, 49, 213.

10 W. Oelerich, T. Klassen and R. Bormann, J. Alloys Compd., 2001, 315, 237.

11 G. Barkhordarian, T. Klassen and R. Bormann, J. Phys. Chem. $B, 2006,110,11020$.

12 N. Hanada, T. Ichikawa, S. Isobe, T. Nakagawa, K. Tokoyoda, T. Honma, H. Fujii and Y. Kojima, J. Phys. Chem. C, 2009, 113, 13450.

13 T. Zhang, S. Isobe, Y. Wang, N. Hashimoto and S. Ohnuki, RSC Adv., 2013, 3, 6311.

14 P. Kichambare, N. Kijima, S. Honma, S. Ebisu and S. Nagata, J. Phys. Chem. Solids, 1996, 57, 1615.
15 F. Xu, Y. C. Liao, M. J. Wang, C. T. Wu, K. F. Chiu and M. K. Wu, J. Low Temp. Phys., 2003, 131, 569.

16 M. Rygula, S. Kemmler-Sack, T. Nissel and R. P. Hubener, Ann. Phys., 1993, 2, 685.

17 D. W. Murphy, M. Greenblatt, S. M. Zahurak, R. J. Cava, J. V. Waszczak, G. W. Hull, Jr and R. S. Hutton, Rev. Chim. Miner., 1982, 19, 441.

18 E. Moshopoulou, Ph.D. Dissertation, University Joseph Fourier-Grenoble I, Grenoble-France, March 1995.

19 L. H. Yang, C. Dong, H. H. Song, J. Guo and G. C. Fu, Chin. Phys. Lett., 2005, 22, 243.

20 B. Bogdanović, R. A. Brand, A. Marjanović, M. Schwickardi and J. Tölle, J. Alloys Compd., 2000, 302, 36.

21 F. Schüth, B. Bogdanović and M. Felderhoff, Chem. Commun., 2004, 2249.

22 B. Bogdanović, M. Felderhoff and G. Streukens, J. Serb. Chem. Soc., 2009, 74(2), 183.

23 H. W. Langmi, G. S. McGrady, X. Liu and C. M. Jensen, J. Phys. Chem. C, 2010, 114, 10666.

24 G. Barkhordarian, T. Klassen and R. Bormann, J. Alloys Compd., 2004, 364, 242.

25 S. T. Sabitu and A. J. Goudy, Metals, 2012, 2, 219.

26 N. Hanada, T. Ichikawa, S. Hino and H. Fujii, J. Alloys Compd., 2006, 420, 46.

27 N. Hanada, T. Ichikawa and H. Fujii, J. Alloys Compd., 2005, 404, 716.

28 S. Nayebossadri and K. F. Aguey-Zinsou, Phys. Chem. Chem. Phys., 2011, 13, 17683.

29 G. Sandrock, K. Gross and G. Thomas, J. Alloys Compd., 2002, 339, 299.

30 P. Wang, X. D. Kang and H. M. Cheng, J. Phys. Chem. B, 2005, 109, 20131.

31 A. Blomqvist, C. M. Araújo, Jena and R. Ahuja, Appl. Phys. Lett., 2007, 90, 141904.

32 T. Vegge, Phys. Chem. Chem. Phys., 2006, 8, 4853.

33 T. Ma, S. Isobe, E. Morita, Y. Wang, N. Hashimoto, S. Ohnuki, T. Kimura, T. Ichikawa and Y. Kojima, Int. J. Hydrogen Energy, 2011, 36, 12319.

34 J. F. Pelletier, J. Huot, M. Sutton and R. Schulz, J. Alloys Compd., 2003, 384, 319.

35 T. Ma, S. Isobe, Y. Wang, N. Hashimoto and S. Ohnuki, J. Phys. Chem. C, 2013, 117, 10302.

36 S. M. Jo, Electrospun Nanofibrous Materials and Their Hydrogen Storage, ed. J. Liu, InTech, 2012, pp. 181210.

37 W. I. F. David, M. O. Jones, D. H. Gregory, C. M. Jewell, S. R. Johnson, A. Walton and P. P. Edwards, J. Am. Chem. Soc., 2007, 129, 1594.

38 R. J. Cava, D. W. Murphy and S. Zahurak, J. Solid State Chem., 1984, 53, 64.

39 O. W. Johnson, Phys. Rev., 1964, 136, A284. 